\title{
High Dosage of Botulinum Toxin Type A in Adult Subjects with Spasticity Following Acquired Central Nervous System Damage: Where Are We at?
}

\author{
Domenico Intiso $^{1, *}$, Valentina Simone ${ }^{1}$, Michelangelo Bartolo ${ }^{2}$, Andrea Santamato ${ }^{3}$, \\ Maurizio Ranieri ${ }^{3}$, Maria Teresa Gatta ${ }^{1}$ and Filomena Di Rienzo ${ }^{1}$ \\ 1 Unit of Neuro-Rehabilitation Unit and Rehabilitation Medicine, IRCCS 'Casa Sollievo della Sofferenza', \\ Viale dei Cappuccini 1, San Giovanni Rotondo, 71013 Foggia, Italy; v.simone@operapadrepio.it (V.S.); \\ mt.gatta@operapadrepio.it (M.T.G.); f.dirienzo@operapadrepio.it (F.D.R.) \\ 2 Department of Rehabilitation, Neurorehabilitation Unit, HABILITA Zingonia, Ciserano, 24040 Bergamo, \\ Italy; bartolomichelangelo@gmail.com \\ 3 Department of Physical Medicine and Rehabilitation, OO.RR Hospital, University of Foggia, 71122 Foggia, \\ Italy; andrea.santamato@unifg.it (A.S.); maurizio.ranieri@uniba.it (M.R.) \\ * Correspondence: d.intiso@operapadrepio.it
}

Received: 15 April 2020; Accepted: 7 May 2020; Published: 10 May 2020

\begin{abstract}
Spasticity is a common disabling disorder in adult subjects suffering from stroke, brain injury, multiple sclerosis (MS) and spinal cord injury (SCI). Spasticity may be a disabling symptom in people during rehabilitation and botulinum toxin type A (BTX-A) has become the first-line therapy for the local form. High BTX-A doses are often used in clinical practice. Advantages and limitations are debated and the evidence is unclear. Therefore, we analysed the efficacy, safety and evidence for BTX-A high doses. Studies published from January 1989 to February 2020 were retrieved from MEDLINE/PubMed, Embase, Cochrane Central Register. Only obabotulinumtoxinA (obaBTX-A), onabotulinumtoxinA (onaBTX-A), and incobotulinumtoxinA (incoBTX-A) were considered. The term "high dosage" indicated $\geq 600 \mathrm{U}$. Thirteen studies met the inclusion criteria. Studies had variable method designs, sample sizes and aims, with only two randomised controlled trials. IncoBTX-A and onaBTX-A were injected in three and eight studies, respectively. BTX-A high doses were used predominantly in treating post-stroke spasticity. No studies were retrieved regarding treating spasticity in MS and SCI. Dosage of BTX-A up to $840 \mathrm{U}$ resulted efficacious and safety without no serious adverse events (AEs). Evidence is insufficient to recommend high BTX-A use in clinical practice, but in selected patients, the benefits of high dose BTX-A may be clinically acceptable.
\end{abstract}

Keywords: botulinum toxin; spasticity; high doses; rehabilitation

Key Contribution: The advantages and limitations, and the evidence of higher BTX-A doses in treating spasticity following CNS damage, is unclear. Dosages of both onaBTX-A and incoBTX-A up $840 \mathrm{U}$ were efficacious and had a good safety profile without serious adverse events, particularly in post-stroke spasticity, but there was insufficient evidence to recommend routine use in clinical practice. In selected patients, the benefits of high dose BTX-A may outweigh the risks of AEs and may be clinically acceptable.

\section{Introduction}

Spasticity is a common disabling disorder in adult subjects suffering from upper motor neuron syndrome (UMNS) and generally develops after lesions of the central nervous system (CNS) such as those caused by stroke, brain injury, spinal cord injury (SCI), multiple sclerosis (MS) and cerebral 
palsy $(\mathrm{CP})$. The physiopathology and muscular changes are not fully clear, though many definitions have been proposed; Lance's definition remains the most diffuse and widely accepted. Accordingly, spasticity is a motor disorder characterised by a velocity-dependent increased resistance to passive limb movement with increased muscle tone and hyperactive reflexes [1]. On the other hand, a key role has been attributed to muscle tissue change, consequently, it is defined as pathological neuromuscular activation and hyper-resistance around joints due to modification of visco-elastic muscle components [2]. Regardless of the pathophysiological mechanisms underlying this motor and muscular tone condition, spasticity may be a disabling and challenging symptom in people during the rehabilitation process and recovery. The disorder can hamper the functional outcome and contributes to the loss of motor dexterity and ability by promoting a persistent abnormal posture, muscular-tendon contractures, bone deformity and a poor quality of life. Therefore, to reduce its negative impact and to improve functional limitations, several therapeutic strategies, including non-pharmacological and pharmacological strategies, have been proposed. Spasticity can occur among the spectrum of UMNS symptoms that include weakness, fatigue, spasms and clonus and, thus, the clinical picture can be variable depending on the sites involved and extension or neuronal tissue damage. Moreover, spasticity can be segmental, involving limited sites of the body, or generalised, involving both the upper and lower limbs. Several medical and surgical therapeutic strategies have been proposed for generalised spasticity. Conversely, botulinum toxin type A (BTX-A), by inhibiting the release of pre-synaptic acetylcholine at neuromuscular junctions, has become the first-line therapy for treating focal or segmental spasticity. Current clinical recommendations for muscle-specific dosing, sites of injection, dosage and dilution as well as the formulation of BTX and adjunct treatments to boost effects are based on the injector's decision [3]. Although widely debated, the BTX-A doses for muscle and the total injection dosage for sessions remain unclear [4]. In this regard, the European Consensus conference recommended that the BTX dosage should not exceed $600 \mathrm{U}$ and $1500 \mathrm{U}$ for injection sessions when using onaBTX-A and aboBTX-A, respectively [5]. Likewise, consensuses have been agreed about the muscles and sites of injection [6]. However, the BTX dosage is largely titrated by the practitioner based on the individual patient response and spastic pictures of patients in order to obtain specific functional goals [7]. The global dosage injected per muscle or multiple muscle groups has progressively increased over time and higher BTX dosages than that recommended are often used in clinical practice and real-world use [7,8], particularly in post-stroke spasticity. Furthermore, experts and patients have highlighted a desire for greater flexibility in treatment options, with more dosages available other than those currently approved [8-10]. The reasons this therapeutic approach is generally justified are its ability to reduce severe spasticity and to give a more tailored treatment in patients with multi-level spastic muscles [11,12]. The risk of diffusion and occurrence of severe side effects represent important concerns regarding the injection of high doses. Several studies have studies the injection of high-dose BTX in treating spasticity, but the indications, advantages and limitations are the object of debate, and the evidence from published studies is unclear. Herein, we will discuss the efficacy, safety and evidence for the use of high dose BTX-A in treating spasticity following common neurological disorders due to CNS damage in adult patients requiring rehabilitation.

\section{$B T X-A$}

Botulinum neurotoxin (BTX), so called botulinum toxin, is a protein synthesized by the Gram-negative anaerobic bacteria Clostridium botulinum. It occurs in the form of seven serologically distinct types, each of which comprises numerous isoforms. Most of the research available in the medical literature regards the neurotoxin type A (BTX-A). The classic site of the impact of the toxin is the protein complexes of the presynaptic membrane and synaptic vesicles, implementing the acetylcholine exocytosis. Type A botulinum toxin can be effective in the treatment of drug-resistant migraine. It is also widely used in aesthetic medicine for the correction of age-related changes in muscle tension, but also otherwise for the treatment of painful bladder, chronic myalgia, blepharospasm and some kinds of neuralgia. In recent decades, several BTX-A formulations have been manufactured 
by Asian and Brazilian pharmaceutical industries and licensed by the Health Agency. Hereby, the following formulations mainly used in Europe and USA will be considered: abobotulinumtoxinA, Ipsen Biopharm Ltd (ObaBTX-A); onabotulinumtoxinA, Allergan Inc (OnaBTX-A) and incobotulinumtoxinA,

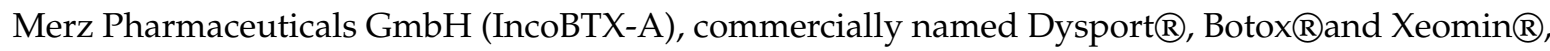
respectively. OnaBTX-A and obaBTX-A are composed of $150 \mathrm{kD}$ active neurotoxin and non-toxic accessory proteins, whereas incoBTX-A contains only the $150 \mathrm{kD}$ neurotoxin [13]. The agents are not interchangeable and there are no validated conversion ratios. Since incoBTX-A has a similar clinical efficacy and adverse event profile as onaBTX-A, it is suggested that the dose ratio should be 1:1 or 1:2; whereas a variable dose ratio from 1:3 to 1:5 has been proposed for the conversion between ona- and aboBTX-A [14-16].

In the present paper, the term "high dosage" is considered as neurotoxin doses injected in a single session higher than $600 \mathrm{U}$ for onaBTX-A and incoBTX-A and higher than $1500 \mathrm{U}$ for aboBTX-A toxins.

\section{Results}

\subsection{Stroke}

Stroke is a leading cause of disability worldwide and spasticity occurs with a range from $18 \%$ to $43 \%$ [17-19]. Thus far, post-stroke spasticity (PSS) is widely treated by BTX-A and several health drug agencies, including the U.S. Food and Drug Administration (FDA) and European Regulatory Agencies, have licensed BTX types and formulations as well as doses to inject for upper (ULS) and lower limb spasticity (LLS). In this regard, in USA and Europe, onaBTX-A (Botox), obaBTX-A (Dysport) and incoBTX-A (Xeomin) have been approved to treat ULS, while only onaBTX-A (Botox) and obaBTX-A (Dysport) have been approved to treat LLS. Accordingly, doses up to $400 \mathrm{U}$ for onaBTX-A and incoBTX-A, and 500-1000 U for obaBTX-A, have been approved for treating ULS. Likewise, doses of 300-400 U for Botox, and up $1500 \mathrm{U}$ for Dysport, have been approved for LLS. There is now a well-established body of evidence demonstrating the safety and efficacy of BTX-A in reducing spasticity both in the upper and the lower limb [20-23]. A multitude of studies and several guidelines have been published reporting recommendations and evidence classes for muscles, dosage and dose intervals for injection when using BTX-A to treat PSS [6]. Although guidelines in Europe allow for doses up to $600 \mathrm{U}$ of onaBTX-A in adults with spasticity [5], many studies have been published about the injection of higher doses of BTX-A in subjects with PSS, and three reviews have focused this topic [24-26]. The literature search identified 1730 citations, but only 13 studies met the inclusion criteria The studies varied in method design, had small or mixed samples and only two studies included a randomised controlled design [27,28]. Of these, the effect of high doses of BTX-A in reducing spasticity were investigated only in one trial [27]. Similarly, the aim of investigations was variable and only a few studies focused on the effects and safety of higher doses of BTX-A than recommended. IncoBTX-A and onaBTX-A were predominantly used. BTX-A formulation alone or associated with other treatments were injected in three and eight studies for onaBTX-A and incoBTX-A, respectively. Two studies used both onaBTX-A and incoBTX-A formulations $[28,29]$. High-dosage aboBTX-A was described in only one study. Below, we describe all studies regarding the injection of BTX-A high dosage that enrolled homogeneous samples of patients with stroke or mixed samples that included subjects suffering from this disease. Studies with mixed samples not including stroke or not reporting causes of spasticity are discussed in different paragraphs of the present paper. The studies have been shared for the authorised types of BTX-A.

Table 1 shows all reported studies, apart from case reports or those describing single subjects.

\subsubsection{AbobotulinumtoxinA (Dysport)}

Only one study has been published reporting high dosage aboBTX-A in subjects with PSS. Six patients were efficaciously treated by 2000 U for LLS [30] and only one subject demonstrated side effects, consisting of bladder paresis. 


\subsubsection{OnabotulinumtoxinA (Botox)}

High dosage of onaBTX-A injections has been reported in six studies, but only three were included in the present review since three of these studies were case reports describing adverse events [31-33]. All trials investigated the effectiveness and safety of high dose onaBTX-A in reducing spasticity of post-stroke subjects, even if different method designs were used $[17,27,34]$. Of these, two studies used a retrospective design. The former reported a cohort of 26 post-stroke subjects who were injected with a mean dose of $676.9 \pm 86.3 \mathrm{U}$ of onaBTX-A. Twenty-three patients were treated at both upper and lower limbs and 13 patients received $700 \mathrm{U}$. A significant reduction in spasticity was observed $(p<0.0001)$, and no adverse events occurred [34]. The latter study included a mixed sample of patients [12] with dystonia and spasticity to evaluate the safety of onaBTX-A injections at dosages higher than $400 \mathrm{U}$. The study enrolled 68 patients and, of these, 24 had spasticity following stroke, brain injury and cerebral palsy. A mean total dose of $501 \pm 46 \mathrm{U}$ (range 425-800 U) was injected. The mean follow-up period was 23 months (range 3-86). All patients reported a benefit after the first treatment ( $8.8 \pm 3.1$ weeks). However, 13 patients (19\%) reported AEs at one year, and $7(10 \%)$ at the last follow-up. Severe dysphagia or major AEs requiring hospitalisation or additional interventions were not observed. The authors suggested that onaBTX-A dosages $>400 \mathrm{U}$ in a single session could be safely injected, were efficacious and had lasting benefit. The other study was a randomised, double-blind study and evaluated three doses of onaBTX-A in 45 subjects randomised to 3 groups of 15 patients to treat spasticity in the foot. Each group received $166.7 \pm 30.9 \mathrm{U}, 321.7 \pm 92 \mathrm{U}$ and $540 \pm 124.2 \mathrm{U}$ (high dose) mean doses of onaBTX-A, respectively. All groups showed a significant improvement in spasticity, but patients in the high dose group showed a greater and longer-lasting decrease in strength in both the injected and the non-injected muscle, that in some patients endured for more than 4 weeks [27]. In total, 46 subjects were injected by high onaBTX-A doses excluding those ( 24 patients) treated by Chiu et al., since in these patients spasticity aetiology was not reported.

\subsubsection{IncobotulinumtoxinA (Xeomin)}

Five studies concerned the use of high doses of incoBTX-A. Of these, three studies enrolled only post-stroke patients and two included mixed samples. Of the studies that included only post-stroke subjects, two studies had an open-label, prospective method design and were performed by Santamato et al. $[35,36]$. Both concerned the same sample of patients. The former investigated the effect of incoBTX-A doses up $840 \mathrm{U}$ (range from 750 to $840 \mathrm{U}$ ) injected in muscles of both UL and LL in the same session to reduce multi-level spasticity. The upper limb was injected by a maximum dosage of $540 \mathrm{U}$, whereas a dosage of $340 \mathrm{U}$ was administered into the lower limbs (range 250-340 U). Over 10 days, subjects underwent stretching exercises of the muscles after receiving injections. A significant decrease in spasticity without AEs was observed after 30 and 90 days from the treatment $(p<0.05)$. Furthermore, improvements in functional disability, spasticity-related pain and muscle tone were detected [35]. The latter study reported the effect in this population treated for 2 years by high doses. In a two-year follow-up, repeated high doses of incoBTX-A, administered for eight sets of injections were safe and efficacious in reducing UL and LL spasticity without generalised AEs [36]. The third study, with a homogenous sample of stroke subjects, investigated the effect of incoBTX-A $>600 \mathrm{U}$ on the autonomic nervous system (ANS) by measuring changes in heart rhythm and enrolled 11 (5 M, 6 F, mean age $59.55 \pm 12.8$ years) patients. Subjects were injected with $12 \mathrm{U} / \mathrm{kg}$ of incoBTX-A (range 600-800; mean dosage $677 \pm 69.3 \mathrm{U}$ ). Two recording ECGs were performed, one before neurotoxin injection and the second one 10 days after the treatment. No differences were observed in parameters of heart rate variability [37]. The remaining two studies included subjects with spasticity following several diseases affecting the central nervous system (CNS). Of these, one was a large prospective, multicentre, single arm, open label, dose-titration study (TOWER study). The trial enrolled 155 patients and of these, 132 had PSS. Although a mixed sample, given that most of the subjects had stroke we preferred to describe it in this section. The primary objective was to investigate the safety of high doses of incoBTX-A and the investigators' global assessment of tolerability. One hundred and fifty-five post-stroke subjects 
received escalating doses of 400, 600, and $800 \mathrm{U}$ of incoA in the same body site. One-hundred thirty and seven patients $(88.4 \%)$ completed the study and $82.9 \%(116 / 140)$ received $800 \mathrm{U}$. With escalating total doses, a higher number of spasticity patterns was successfully treated. IncoBTX-A dose escalation from $400 \mathrm{U}$ up to $800 \mathrm{U}$ increased improvements of muscle tone, goal attainment and global efficacy. Transient adverse events occurred for each dose group and there was no increased incidence of adverse effects with increasing doses. The most frequent side effects overall were falls $(7.7 \%)$, nasopharyngitis, arthralgia and diarrhoea (6.5\% each) [38]. Globally, five subjects discontinued treatment due to AEs, but none of these belonged to subjects receiving $800 \mathrm{U}$. No patients developed secondary nonresponses due to neutralising antibodies. The last study by Ianieri et al. reported the effect of escalating doses up $1000 \mathrm{U}$ of incoBTX-A to reduce spasticity according to the individual patient's features and needs. The doses were chosen depending on the severity of spasticity. One hundred and twenty subjects suffering from spasticity due to several pathologies were retrospectively analysed and 58 patients received high incoBTX-A doses from $400 \mathrm{U}$ to $1000 \mathrm{U}$. The authors individualised treatment for three groups of patients who were injected by $\leq 400 \mathrm{U} ; 400-700 \mathrm{U}$ and $700-1000 \mathrm{U}$, respectively. The group treated by incoBTX-A $>700 \mathrm{U}$ was injected by progressively increasing dosages, with a mean dose between $775.65 \pm 30.45$ and $986.65 \pm 13.67 \mathrm{U}$. Transient general weakness was observed in $4 \%$ of subjects [39].

It was not possible to calculate the global number of treated patients, since one study with mixed samples did not report aetiologies of spasticity [39]; however, it was estimated that about 200 patients with PSS were injected with high dose incoBTX-A. 
Table 1. Studies investigating BTX-A high doses in patients with post-stroke spasticity.

\begin{tabular}{|c|c|c|c|c|c|c|c|c|}
\hline $\begin{array}{l}\text { Study/ } \\
\text { Year }\end{array}$ & Design & $\begin{array}{c}\text { Sample/ } \\
\text { Patients/Sex }\end{array}$ & $\begin{array}{c}\text { BTX-Type and } \\
\text { Doses/Guidance/PT }\end{array}$ & Foll-Up & Measures & Adverse Event & $\begin{array}{l}\text { Drop-Out; } \\
\text { Lost }\end{array}$ & Outcome \\
\hline $\begin{array}{l}\text { Santamato et al. } \\
2013 \text { [35] }\end{array}$ & $\begin{array}{l}\text { open label } \\
\text { prospective }\end{array}$ & $\begin{array}{c}\mathrm{N}=25 \\
12 \mathrm{~F}, 8 \mathrm{M} ; \\
\text { age (range } 45-71 \mathrm{yrs})\end{array}$ & $\begin{array}{c}\text { incobotulinumtoxinA (Xeomin) } \\
840 \mathrm{U} \text { (ranged } \\
\text { from } 750 \text { to } 840 \mathrm{U} \text { ) in both UL } \\
\text { and LL; } \\
\text { UL muscles received a dosage of } \\
\text { maximum } 540 \mathrm{U} ; 340 \mathrm{U} \text { was } \\
\text { administered in LL (range } \\
\text { 250-340 U); US; } \\
\text { stretching exercises of the muscles } \\
\text { injected for } 10 \text { days }\end{array}$ & $3 \mathrm{mo}$ & $\begin{array}{l}\text { AS; DAS; GATR; } \\
\text { VAS }\end{array}$ & no adverse event & - & $\begin{array}{l}\text { improvement in } \\
\text { disability, } \\
\text { spasticity-related pain, } \\
\text { and muscle tone. } \\
\text { Significant decrease } \\
\text { evaluated after } 30 \text { and } 90 \\
\text { days from the treatment } \\
\quad(p<0.05)\end{array}$ \\
\hline $\begin{array}{l}\text { Invernizzi et al. } \\
2014 \text { [37] }\end{array}$ & Case control & $\begin{array}{c}\mathrm{N}=11 \\
5 \mathrm{M}, 6 \mathrm{~F} \\
\text { age from } 44 \text { to } 72 \mathrm{yrs}\end{array}$ & $\begin{array}{c}\text { incobotulinumtoxinA (Xeomin) } \\
\text { higher 600 U; } 12 \mathrm{U} / \mathrm{kg} \text { (range } \\
600-800) ; \mathrm{NR}\end{array}$ & & $\begin{array}{c}\text { AS > 2; } \\
\text { ECG for HRV (RR } \\
\text { interval) }\end{array}$ & $\begin{array}{l}\text { no effect on RR } \\
\text { interval }\end{array}$ & - & $\mathrm{N} / \mathrm{A}$ \\
\hline $\begin{array}{l}\text { Baricich et al. } \\
2015 \text { [34] }\end{array}$ & $\begin{array}{l}\text { cohort; } \\
\text { retrospective }\end{array}$ & $\begin{array}{c}\mathrm{N}=26 ; \\
\text { M 13, F 13; } \\
\text { mean age 54.7 } \pm 11.6\end{array}$ & $\begin{array}{c}\text { onabotulinumtoxinA (Botox) } \\
600 \mathrm{IU} ; \\
13 \text { pts > 700 IU; mean dose } \\
676.9 \pm 86.3 \mathrm{IU} ; \mathrm{US} ; \\
23 \text { pts were treated at both upper } \\
\text { and lower limb; } \\
\text { electrical stimulation and } \\
\text { stretching of injected muscles, } \\
\text { strengthening exercise, gait } \\
\text { training }\end{array}$ & $3 \mathrm{mo}$ & MAS; DAS; GAE & no adverse event & - & $\begin{array}{l}\text { significant reduction of } \\
\text { spasticity } \\
(p<0.0001)\end{array}$ \\
\hline $\begin{array}{l}\text { Mancini et al. } \\
2015[27]\end{array}$ & $\begin{array}{l}\text { randomised, } \\
\text { double-blind, } \\
\text { dose-ranging } \\
\text { study }\end{array}$ & $\begin{array}{c}\quad \mathrm{N}=45 \mathrm{pts} ; \\
\mathrm{N}=15 \mathrm{pts} \\
\text { with onaBTX-A high } \\
\text { dosage; } \\
(\mathrm{M} 8, \mathrm{~F} 7) \text { mean age } \\
63.2 \pm 10.1\end{array}$ & $\begin{array}{l}\text { onabotulinumtoxinA (Botox) } \\
540 \pm 124.2 \mathrm{U} \text {; EMG }\end{array}$ & $4 \mathrm{mo}$ & $\begin{array}{l}\text { MRC; MAS; } \\
\text { VAS GT; GV; }\end{array}$ & $\begin{array}{l}\text { prolonged weakness } \\
\text { of the treated limb, } \\
\text { flu-like syndrome and } \\
\text { oedema of the } \\
\text { injected leg, in some } \\
\text { patients enduring for } \\
\text { more than } 4 \text { weeks }\end{array}$ & - & $\begin{array}{l}\text { prolonged effect of BTX } \\
\text { on spasticity, GV, gait } \\
\text { function, pain and } \\
\text { presence of clonus }\end{array}$ \\
\hline $\begin{array}{l}\text { Santamato et al. } \\
2017 \text { [36] }\end{array}$ & $\begin{array}{l}\text { open label } \\
\text { prospective }\end{array}$ & $\begin{array}{c}25 \mathrm{pts} ; \\
20(12 \mathrm{~F}, 8 \mathrm{M}) \\
\text { mean age } 60.8 \pm 7.8\end{array}$ & $\begin{array}{c}\text { incobotulinumtoxinA (Xeomin); } \\
830 \mathrm{U} \text { (ranged from } 750 \mathrm{U} \text { to } 830 \mathrm{U} \text { ) } \\
\text { in both upper and lower limb; US; } \\
\text { upper limb muscles received a } \\
\text { dosage of maximum } 560 \mathrm{U} ; \mathrm{a} \\
\text { dosage of maximum } 460 \mathrm{U} \text { was } \\
\text { administrated into lower limbs } \\
\text { (ranged from } 260 \mathrm{U} \text { to } 460 \mathrm{U} \text { ); } \\
\text { stretching exercises of the muscles } \\
\text { injected for } 10 \text { days }\end{array}$ & $2 \mathrm{yrs}$ & AS; DAS; GATR & no adverse event & $5 \mathrm{pts}$ & $\begin{array}{l}\text { improvements as } \\
\text { assessed on clinical scales } \\
\text { for spasticity (AS), } \\
\text { disability (DAS) and } \\
\text { global assessment of } \\
\text { treatment response } \\
\text { (GATR) }\end{array}$ \\
\hline
\end{tabular}


Table 1. Cont

\begin{tabular}{|c|c|c|c|c|c|c|c|c|}
\hline $\begin{array}{l}\text { Study/ } \\
\text { Year }\end{array}$ & Design & $\begin{array}{c}\text { Sample/ } \\
\text { Patients/Sex }\end{array}$ & $\begin{array}{c}\text { BTX-Type and } \\
\text { Doses/Guidance/PT }\end{array}$ & Foll-Up & Measures & Adverse Event & $\begin{array}{l}\text { Drop-Out; } \\
\text { Lost }\end{array}$ & Outcome \\
\hline $\begin{array}{l}\text { Wissel et al. } \\
2017 \text { [38] }\end{array}$ & $\begin{array}{l}\text { prospective, } \\
\text { single-arm, } \\
\text { dose-titration } \\
\text { study }\end{array}$ & $\begin{array}{c}\text { mixed sample } \\
\mathrm{N}=155 \text { pts } \\
\mathrm{M} 104 ; \mathrm{F} 51 ; \\
\text { mean age } \\
53.7 \pm 13.1 \\
\mathrm{~N}=132 \text { with stroke; } \\
\mathrm{N}=23 \text { other causes }\end{array}$ & $\begin{array}{l}\text { incobotulinumtoxinA } \\
\text { (Xeomin) } 400 \text { to } 800 \mathrm{IU}\end{array}$ & $36-48 \mathrm{wks}$ & $\begin{array}{l}\text { AS; REPAS; GAS; } \\
\text { Investigators' } \\
\text { global assessment } \\
\text { of tolerability; } \\
\text { Investigators' and } \\
\text { patients' global } \\
\text { assessments of } \\
\text { efficacy }\end{array}$ & $\begin{array}{c}\text { no treatment-related } \\
\text { serious adverse event } \\
\text { (AE) occurredN= } 5 \\
\text { pts;The most frequent } \\
\text { AEs overall were falls } \\
(7.7 \%), \\
\text { nasopharynitis, } \\
\text { arthralgia, and } \\
\text { diarrhea ( } 6.5 \% \text { each) }\end{array}$ & $18 \mathrm{pts}$ & $\begin{array}{l}\text { dosage up to } 800 \mathrm{U} \text { was } \\
\text { safe and was associated } \\
\text { with increased treatment } \\
\text { efficacy, improved muscle } \\
\text { tone, and goal attainment }\end{array}$ \\
\hline $\begin{array}{l}\text { Baricich et al } \\
2017[28]\end{array}$ & $\begin{array}{l}\text { single blind } \\
\text { randomized } \\
\text { controlled } \\
\text { crossover study } \\
\text { design }\end{array}$ & $\begin{array}{c}10 \mathrm{pts} \\
7 \mathrm{M}, 3 \mathrm{~F} \\
\text { age } 69 \pm 10.5\end{array}$ & $\begin{array}{c}\mathrm{N}=5 \text { onabotulinumtoxinA }(\text { Botox }) \\
600 \mathrm{U}(670 \pm 83.67) ; \\
\mathrm{N}=5 \text { IncobotulinumtoxinA } \\
\text { (Xeomin) }(660 \pm 89.44) ; \\
\text { doses below } 12 \text { units/Kg }\end{array}$ & N/A & $\begin{array}{l}\mathrm{AS} ; \mathrm{BI} ; \mathrm{MI} \text {; and FAC } \\
\text { score }\end{array}$ & - & N/A & $\begin{array}{l}\text { no influence on the } \\
\text { cardiovascular activity of } \\
\text { the autonomic nervous } \\
\text { system in chronic } \\
\text { hemiplegic spastic stroke } \\
\text { survivors. }\end{array}$ \\
\hline $\begin{array}{l}\text { Ianieri et al. } \\
2018 \text { [39] }\end{array}$ & retrospective & $\begin{array}{c}\text { mixed sample }^{\circ} \\
\mathrm{N}=120 \\
\mathrm{~N}=58 \\
\mathrm{M} 28, \mathrm{~F} 22 \\
\text { mean age } \\
66 \pm 3.2\end{array}$ & $\begin{array}{c}\text { incobotulinutoxinA } \\
\mathrm{N}=58 \text { received } 700-1000 \mathrm{U} \text { (from } \\
775.65 \pm 30.45 \text { to } 986.65 \pm 13.67) \\
\mathrm{NR} ; \\
\text { stretching of injected muscles, } \\
\text { active and } \\
\text { passive limb mobilization, walking } \\
\text { training, and global muscle } \\
\text { strengthening, daily for the first } 30 \\
\text { days after injection }\end{array}$ & $2 \mathrm{yrs}$ & $\begin{array}{c}\text { AS; FIM; } \\
\text { MyotonPRO }\end{array}$ & $\begin{array}{l}\text { Dysphagia }(2 \%), \text { local } \\
(4 \%) \text { and general } \\
\text { muscle weakness } \\
(4 \%) ;\end{array}$ & - & $\begin{array}{l}\text { reduction of spasticity } \\
\text { with mild transient AEs } \\
\text { consisting in local } \\
\text { weakness (3.3\%)and } \\
\text { generalized weakness } \\
(4 \%) \text { in group injected by } \\
\text { higher dosage (from } \\
700 \text { U to } 1000 \mathrm{U})\end{array}$ \\
\hline $\begin{array}{l}\text { Chiu SY et al. } \\
2020 \text { [12] }\end{array}$ & retrospective & $\begin{array}{c}\text { mixed sample } \\
\mathrm{N}=68 \text { pts } \\
\mathrm{F} 43, \mathrm{M} 25 ; \\
\mathrm{N}=24 \text { with spasticity } \\
* \text {, remaining affected } \\
\quad \text { by dystonia } \\
* *\end{array}$ & $\begin{array}{c}\text { onabotulinumtoxinA } \\
\text { (Botox) }>400 \mathrm{U} \text { receiving doses up } \\
\text { to } 800 \mathrm{U} \text {; NR }\end{array}$ & 12 mo up 86 mo & $\begin{array}{l}\text { 7-point Clinical } \\
\text { Global Impression } \\
\text { Scale (CGIS) }\end{array}$ & $\begin{array}{l}\text { Ten patients }(15 \%) \\
\text { reported adverse } \\
\text { effects (AEs) at the } \\
\text { first follow-up; } 13 \\
\text { patients (19\%) } \\
\text { reported AEs at } 1 \text { year. } \\
\text { The most common AE } \\
\text { reported was bruising }\end{array}$ & $\begin{array}{l}38 \text { pts at last } \\
\text { fol.-up }\end{array}$ & $\begin{array}{l}\text { all patients reported } \\
\text { benefit after first } \\
\text { treatment } \\
(8.8 \text { weeks } \pm 3.1)\end{array}$ \\
\hline $\begin{array}{l}\text { Legend: } \mathrm{N} \\
\text { assessmen } \\
\text { scale; FAC } \\
\text { MRC }=\mathrm{M} \\
\text { cerebral pr } \\
\text { and cerebr }\end{array}$ & $\begin{array}{l}\text { not applicabl } \\
\text { le; GAE = gl } \\
\text { unctional am } \\
1 \text { Research C } \\
\text { brain tumor; } \\
\text { lsy; ** prima }\end{array}$ & $\begin{array}{l}\mathrm{R}=\text { not reported; I } \\
\text { assessment of eff } \\
\text { tion category sco } \\
\text { il scale; REPAS = } \\
\text { sticity due to stro } \\
\text { vstonia, idiopathi }\end{array}$ & $\begin{array}{l}\text { Physical therapy; EMG = elec } \\
\text {; GV = gait velocity; GAS = } \\
\text { IRV = heart rate variability; } \\
\text { stance to Passive Movement } \\
\text { aumatic brain injury, multip } \\
\text { kinson's disease, or atypical }\end{array}$ & $\begin{array}{l}\text { ography; U } \\
\text { attainment } \\
\text { = Function } \\
\text {; VAS = vis } \\
\text { rosis, spina }\end{array}$ & $\begin{array}{l}\text { trasonographic } \\
\text {; GATR = globa } \\
\text { ependence mea } \\
\text { talogue scale; V } \\
\text { injury; * spasti } \\
\text { he. }\end{array}$ & $\begin{array}{l}\text { le; AS = Ashworth sc } \\
\text { sessment of treatme } \\
\text {; MAS = modified } \\
\text { iT = Visual Analog } \\
\text { common etiologies }\end{array}$ & $\begin{array}{l}\text { BI = Barthe } \\
\text { sponse; } \mathrm{G} \\
\text { vorth scal } \\
\text { le for Gai } \\
\text { ided strok }\end{array}$ & $\begin{array}{l}\text { dex; DAS = disability } \\
=\text { Glasgow outcome } \\
\text { II = Motricity Index; } \\
\text { inction. `brain injury, } \\
\text { aumatic brain injury, }\end{array}$ \\
\hline
\end{tabular}




\subsubsection{OnaA or IncoA}

Two studies used onaBTX-A or incoBTX-A. The former by Baricich et al. compared the effect of high doses of onaBTX-A and incoBTX-A on the cardiovascular activity of the ANS in chronic hemiplegic spastic stroke survivors [28]. The study used a single randomised controlled crossover method design and enrolled a very small sample. Ten patients (mean age $69 \pm 10.5$ ) were randomised into 2 groups of 5 subjects and each group received onaBTX-A or incoBTX-A doses higher $600 \mathrm{U}$. The onaBTX-A group was injected by a mean dosage of $670 \pm 83.67 \mathrm{U}$ and the incoBTX-A group by a mean dosage of $660 \pm 89.44 \mathrm{U}$ (doses below 12 units/Kg). No effect was observed [28]. The latter by Kirshblum $\mathrm{S}$ et al. [29] was a retrospective study to determine differences in risk of AEs when using doses higher that $600 \mathrm{U}$ of onaBTX-A or incoBTX-A as compared to lower doses. The study investigated a large sample of 342 subjects suffering from dystonia and spasticity, but only 42 patients received doses higher than $600 \mathrm{U}$. The aetiology of spasticity was not reported. In this group, doses higher $600 \mathrm{U}$ were found to increase the rate of adverse effects.

\subsection{Brain Injury}

Spasticity frequently occurs after brain injury and many studies and meta-analysis have been reported about the use of BTX-A in treating UL and LL in this disorder [40-42]. Although subjects suffering from spasticity following brain injury may show complex features and multi-level muscle involvement, few studies have investigated the efficacy and safety of high dose BTX-A. The literature research produced 246 citations, but only 4 studies were included $[12,38,39,43]$. The studies had variable method designs and enrolled mixed samples including patients with spasticity following several disorders affecting the CNS, including brain injury, stroke and cerebral palsy (CP). Globally, 27 subjects were injected by high dose BTX-A, including onaBTX-A or incoBTX-A formulations. Of these, $16(72.3 \%)$ subjects were enrolled in the study by Intiso et al. and $11(7.1 \%)$ were enrolled in the study by Wissel et al. (which has been described in this manuscript under the stroke subheading). Intiso et al. evaluated the effect of incoBTX-A doses higher $700 \mathrm{U}$ in 22 patients $(12 \mathrm{M}, 10 \mathrm{~F}$; mean age 38.1 \pm 13.7 ). The sample included 16 subjects with brain injury and 6 with CP. All subjects with hemiparesis received neurotoxin injections in both the upper and lower limbs in the same session, with doses ranging from 770 to $840 \mathrm{U}$. Significant spasticity and pain reduction was detected after BTX-A injections. Side effects were transient and consisted of hematoma in the site of injection (2 subjects) and weakness of the injected arm lasting 2 weeks (one subject) [43]. The study by Wissel et al. at investigated escalating doses of incoBTX-A. In this study, 155 subjects were enrolled, but only $11(7.1 \%)$ suffered from traumatic brain injury [38]. The remaining two investigations did not report the number of spastic subjects according to aetiology [39] or spasticity aetiology [29]. Since these studies had mixed samples, the investigation by Ianieri et al. was described in the stroke paragraph and that by Kirshblum et al. was reported in the paragraph concerning studies with mixed samples.

\subsection{Multiple Sclerosis}

The literature search produced 246 citations, but no study investigated high doses of BTX-A in treating spasticity following MS. Patients with MS can show complex neurological features due to lesions in sensory-motor and other neuronal pathways. Spasticity is a common and troublesome symptom with a variable prevalence from $30 \%$ and $60 \%$, and up to $80 \%$, in some series [44,45]. It can involve local or multi-level body sites. BTX-A has long been used in the symptomatic treatment of MS patients, such as for a hyperactive bladder [46]. Likewise, studies and reviews [47-49] have reported BTX-A use for the treatment of spasticity, but few randomised trials have been performed. In this regard, the review by Dressler et al. 2017 [49] found only three RCTs [50-52], and a recent Italian consensus on spasticity treatment considered only 4 trials concerning BTX [53]. Of these, two trials were randomised double-blind, placebo-controlled studies [50,52]; one [50] with a crossover design and two single-blind randomised trials [54,55]. In these studies, doses from 500 to $1500 \mathrm{U}$ and 
from 100 to 400 UI for aboBTX-A and onaBTX-A were injected, respectively. Interestingly, one trial investigated the effect of aboBTX-A in 74 patients with MS and spasticity affecting the hip adductor muscles of both legs [52]. Subjects were randomised to 500, 1000 and $1500 \mathrm{U}$ or placebo. The optimal dose for treating hip adductor spasticity was considered 500-1000 U of aboBTX-A, but the higher dose of $1500 \mathrm{U}$ was suggested to provide greater benefit and was safe without major side effects [52]. Among BTX-A formulations, aboBTX-A and onaBTX-A were predominantly injected to treat spasticity, apart from in one study with mixed samples that used incoBTX-A [39] neurotoxin. All studies showed a significant efficacy of BTX in reducing spasticity due to MS [47-49]. BTX-A dosages up to 2000 UI for Dysport [56,57] and up to 400 UI for Botox were injected without significant side effects. European neurological Societies have published consensuses and guidelines for treating spasticity in patients suffering from MS $[53,58]$ and have drawn up therapeutic algorithms. Accordingly, BTX-A has limited use and has been suggested only for focal spasticity. Despite this, BTX-A was easily administered and has not been associated with adverse effects to date, and no studies have been performed enrolling only subjects with MS in order to analyse the effect of high dose BTX-A. Subjects with MS were injected with high doses of incoBTX-A or onaBTX-A in one study that enrolled mixed samples [39], but limited information can be obtained (Table 2).

\subsection{Spinal Cord Injury}

The literature search produced 350 citations, but as for MS, no study investigated high doses of BTX-A in treating spasticity due to SCI. Spasticity is a frequent disorder following SCI and it is often associated with troublesome symptoms such as pain and spams that may be resistant to common therapeutic agents and worsen daily life [59]. Complicated spasticity is difficult to manage, requiring multiform interventions and multidisciplinary teams. In this regard, combined rehabilitative and pharmacological strategies have been proposed to reduce spasticity, relieve pain and improve quality of life. BTX-A is commonly used in treating coexistent symptoms such as overactive bladder [60,61] and neuropathic pain that is refractory to common analgesic agents [62-64]. In post-traumatic SCI, a prevalence between $60 \%$ and $80 \%$ has been reported and $35 \%$ had severe spasticity $[65,66]$. Although spasticity is a common disorder following SCI, few investigations have been performed to analyse the effect of BTX-A $[67,68]$ and no studies have investigated high dose BTX-A in reducing spasticity in subjects with SCI.

\subsection{Studies with Mixed Samples: Dystonia and Spasticity}

Four studies investigating high dose BTX-A injections enrolled subjects with dystonia and spasticity due to disorders affecting the CNS (Table 2). IncoBTX-A was predominantly used, and incoBTX-A and onaBTX-A or IncoBTX-A neurotoxins were injected in three and one studies, respectively. The primary aim of these studies was to ascertain the safety of high doses of BTX-A. Of these, 2 studies were performed by Dessler et al., 2009 [11,69]. The former evaluated the efficacy and safety of incoBTX-A in patients previously treated by onaBTX-A [69]. Two-hundred and sixty-three patients were injected and, of these, 84 had spasticity, even if the aetiology was not reported. Subjects with spasticity were injected with $450.5 \pm 177.1 \mathrm{U}$ and those with generalised spasticity received the highest incoBTX-A doses, with an average dose of $552.2 \pm 217.1 \mathrm{U}$. The maximal incoBTX-A dose applied to a single patient was $840 \mathrm{U}$, and none of the patients experienced any motor or non-motor systemic AEs. The latter was a prospective non-interventional study that evaluated high incoBTX-A doses compared to regular doses in 100 patients with dystonia or spasticity [11]. Fifty-four subjects suffered from spasticity and received a mean dose of incoBTX-A of $612.6 \pm 176.5 \mathrm{U}$ ( $\min 400, \max 1200 \mathrm{U}$ ). The author affirmed that incoBTX-A could be safely used in doses $\geq 400 \mathrm{U}$ and up to $1200 \mathrm{U}$ without detectable systemic toxicity and concluded that this allows injection of more target muscles and also of higher incoBTX-A doses per target muscle, where necessary. Given that it predominantly enrolled subjects with brain injury, the study by Intiso et al. has been described in the related section above [43]. Likewise, the study by Kirshblum $S$ et al. that injected subjects with dystonia and spasticity has been reported under the stroke subheading [29]. 
Table 2. Studies that enrolled mixed samples. Subjects with dystonia and spasticity following disorders of CNS who underwent BTX- A high doses.

\begin{tabular}{|c|c|c|c|c|c|c|c|}
\hline Study & Design & Patients/Sex & $\begin{array}{c}\text { BTX-Type and } \\
\text { Doses/Guidance/PT }\end{array}$ & Follow-Up & Measures & Adverse Event & Outcome \\
\hline $\begin{array}{l}\text { Dressler et al. } \\
2009 \text { [69] }\end{array}$ & open label prospective & $\begin{array}{c}\mathrm{N}=236 \mathrm{pts} \\
\mathrm{N}=84 \text { pts with spasticity \& }\end{array}$ & $\begin{array}{l}\text { incobotulinumtoxinA at } \\
450.5 \pm 177.1 \mathrm{U} \text {;maximum } \\
\text { botulinum toxin dose } \\
\text { applied was } 840 \mathrm{U} ;\end{array}$ & 3 yrs & NR & $\begin{array}{l}\text { none of the patients } \\
\text { experienced systemic } \\
\text { adverse effects, neither } \\
\text { motor nor autonomic ones. }\end{array}$ & $\begin{array}{l}\text { no subjective or objective } \\
\text { differences detectable compared } \\
\text { to Botox previously injected }\end{array}$ \\
\hline $\begin{array}{l}\text { Intiso et al. } \\
2014 \text { [43] }\end{array}$ & open label prospective & $\begin{array}{c}\mathrm{N}=22 \mathrm{pts} ; \\
\text { mean age } 38.1 \pm 13.7 \text { years; } \\
\mathrm{N}=16 \text { with } \mathrm{BI} ; \\
\mathrm{N}=6 \text { with } \mathrm{CP}\end{array}$ & $\begin{array}{l}\text { incobotulinumtoxinA up } \\
\text { to } 840 \mathrm{U} ; \mathrm{US}\end{array}$ & $16 \mathrm{wks}$ & $\begin{array}{l}\text { MAS, MRC, } \\
\text { VAS, FAT, } \\
\text { GOS, BI }\end{array}$ & $\begin{array}{l}\text { hematoma }(2 \mathrm{pts}) ; \text { muscle } \\
\text { weakness and reduction of } \\
\text { active motility of the } \\
\text { injected arm }(1 \mathrm{pt})\end{array}$ & $\begin{array}{l}\text { high-dose BTX-A injections were } \\
\text { effective and safe in reducing } \\
\text { spasticity. Significant reduction of } \\
\text { the pain was also observed }\end{array}$ \\
\hline $\begin{array}{c}\text { Dressler et al. } \\
2015 \text { [11] }\end{array}$ & $\begin{array}{c}\text { prospective non } \\
\text { interventionalrandomized } \\
\text { study }\end{array}$ & $\begin{array}{c}\mathrm{N}=100 \text { pts; } \\
\mathrm{N}=46 \text { pts with dystonia } \\
\mathrm{N}=54 \text { pts with spasticity\&; } \\
33 \mathrm{M}, 21 \mathrm{~F} \text {; mean age } \\
56.1 \pm 14.7 \text { years }\end{array}$ & $\begin{array}{c}\text { incobotulinumtoxinA } \\
612.6 \pm 176.5(\min 400, \max \\
1.200) \mathrm{U} ; \\
\text { EMG or US }\end{array}$ & NR & STQ; & $\begin{array}{l}\text { generalized weakness } \\
(12 \%) ; \text { feeling of residual } \\
\text { urine }(10 \%) \text {;constipation (9); } \\
\text { blurred vision ( } 8 \%), \\
\text { attributed to underlying } \\
\text { neurological condition }\end{array}$ & $\begin{array}{c}\text { doses }>400 \mathrm{U} \text { and up to } 1200 \mathrm{U} \\
\text { without detectable systemic } \\
\text { toxicity were used safely. No } \\
\text { developed Nab }\end{array}$ \\
\hline $\begin{array}{l}\text { Kirshblum } \\
\text { S et al. } \\
2020[29]\end{array}$ & retrospective & $\begin{array}{c}\mathrm{N}=342 \mathrm{pts} \\
\mathrm{F}=190 ; \\
\mathrm{M}=152 \\
\text { Mean age } 53.1 \pm 16.3 \mathrm{yrs} \\
\text { including cervical dystonia } \\
\text { and spasticity \& }\end{array}$ & $\begin{array}{c}\text { onabotulinumtoxinA or } \\
\text { incobotulinumtoxinAN }=42 \\
\text { pts }(14 \%) \text { received } \\
>600 \mathrm{U}\end{array}$ & $3 \mathrm{yrs}$ & - & $\begin{array}{l}\text { subjests receiving > } 600 \\
\text { Uadverse events } \\
(5.6 \%) ; \text { weakness } \\
(4 \%) ; \text { dysphagia }(1.6 \%)\end{array}$ & $\begin{array}{l}\text { increased risk of adverse events } \\
\text { associated with BTX-A doses } \\
\text { higher than } 600 \mathrm{U} \text { (OR } 2.98 \\
\text { CI 1.14-7.78). There was no } \\
\text { difference in adverse events } \\
\text { between onabotulinumtoxinA or } \\
\text { incobotulinumtoxinA }\end{array}$ \\
\hline
\end{tabular}

Legend: NR = not reported; BI = brain injury; CNS= central nervous system; EMG = electromyography; US = ultrasound; GOS = Glasgow Outcome scale; FAT = Frenchay Arm Test; MAS = modified Ashworth scale; MRC = Medical Research Council scale; Nab = neutralizing antibodies; STQ = Systemic toxicity questionnaire; VAS = visual analogue scale \& Spasticity etiology was not specified;. 


\subsection{Safety and Adverse Events}

Local side effects are directly associated with the injections and consist predominantly of transient pain, hematoma and swelling at the injection site, and this lasts for a few days. On the other hand, systemic AEs are related to spread of the toxin to locations distant from the site of injection; these can produce serious conditions such as a botulism-like syndrome which is characterised by dysphagia, general weakness and symptoms that can resemble botulism [70]. Local and generalised AEs have been reported by repetitive BTX A injections at recommended dosage [20,71], but the use of doses higher than recommended may increase the risk of AEs. In this regard, three studies that were not included in the present paper, described AEs induced by injections of high BTX doses. AEs included fatigue and contralateral weakness after $700 \mathrm{U}$ (one subject) [31] and $800 \mathrm{U}$ (one subject) of onaBTX-A injections (three subjects) [32]. The remaining paper described one subject who showed upper and lower weakness, dysarthria, increased falls and gait instability after $650 \mathrm{U}$ of onaBTX-A [33]. No serious AEs were reported by studies included in the present review and only transient and mild side effects were described [12,38,39]. Among the studies that treated post-stroke patients, Mancini et al. reported that some subjects receiving high dose onaBTX-A showed weakness of the treated limb, flu-like syndromes and oedema of the injected leg enduring for more than 4 weeks [27]. The large sample study of 155 studies of incoBTX-A escalating doses reported that in total, 36.1\% (56/155), 37.5\% (57/152), and $25.7 \%(36 / 140)$ of patients reported AEs in cycles 1 (400 U), 2 (600 U) and $3(800 \mathrm{U})$, respectively, and no differences were observed between groups. Furthermore, there was no increased incidence of AEs with increasing doses or repeated injections [38]. Chiu et al. reported that 13 (19\%) patients had AEs at 1 year, and that the most common of these was bruising. However, no patients suffered from serious AEs and only one patient discontinued injection due AEs [12]. Ianieri et al., considering all injections, described only four cases (3.3\%) of excessive local muscle weakness and two cases $(1.6 \%)$ of transient generalised weakness lasting 20 and 10 days, respectively (39). Only 2 (4\%) subjects of group C (700-1000 U) complained of transient generalised muscle weakness. Of studies that enrolled mixed samples, mild AEs consisting of generalised weakness (12\%), feeling of residual urine $(10 \%)$, constipation ( $9 \%$ ) and blurred vision ( $8 \%$ ) were observed by Dressler et al., but these disturbances were attributed to underlying neurological conditions and not to the effect of BTX-A [11]. The study by Kirshblum et al. analysed if adverse events increased when injecting higher doses of BTX-A, and if onaBTX-A or incoBTX-A differed in adverse event rates [29]. They reported that AEs did not increase until doses of BTX-A exceeded $600 \mathrm{U}$. AEs were observed in 7 subjects $(5.6 \%), 4(2.2 \%)$ and $16(2.6 \%)$ treated by $\leq 400 \mathrm{U} ; 400-600 \mathrm{U}$ and $>600 \mathrm{U}$ of BTX-A, respectively. Higher doses $>600$ units were associated with an increased risk of complications (OR 2.98, CI 1.14-7.78). However, the authors calculated that the number needed to harm for most related complications exceeded 80 and suggested that the benefits of high dose BTX-A may outweigh the risks. No statistical difference in AE rate was detected between incoBTX-A and onaBTX-A.

Other potential complications of injecting BTX-A include the occurrence of neutralising antibodies $(\mathrm{Nab})$ [72] that counteract the effect of the neurotoxin. This phenomenon has represented an important consideration, limiting the use of increased doses of BTX. Repeated injections and BTX-A high doses have been considered potential risks in promoting $\mathrm{Nab}[73,74]$. However, no studies included in the present review reported this complication, even if almost all of them did not ascertain Nab by laboratory test; the exception is the study by Wissel et al. that ascertained Nab occurrence with escalating incoBTX-A high doses. Blood samples were taken for antibody and laboratory assessments, but none of the patients developed $\mathrm{Nab}$ or a secondary response.

\section{Discussion}

Studies about the role of high BTX-A injections in treating spasticity following UMNS are scant and there remains insufficient evidence to recommend routine use in clinical practice. The literature search identified 13 studies, according to the selection criteria, and most of these investigated the effect and safety of BTX-A high doses in post-stroke spasticity, but total number of injected subjects 
did not exceed 300. The studies were variable in method design, sample size, sample type, aim, outcome measures and only two were RCTs. Despite the poor quality of studies, high BTX-A dosage up $840 \mathrm{U}$ were efficacious and safe in reducing multilevel spasticity or in treating both UL and LL in same session and certain patients with spasticity might benefit from high dose BTX-A, particularly post-stroke subjects. BTX-A use in treating spasticity due to brain injury was investigated in a few studies, all of which enrolled mixed samples. Of these, only two studies reported the number of injected subjects [38,43], but the total number sample was very small since only 27 patients were identified. Although, spasticity is a common and troublesome complication of MS and SCI, none of the studies investigated the effect and safety of high dose BTX-A in treating spasticity of subjects suffering from these diseases. One study enrolled a sample in which subjects with MS and SCI were also injected with high onaBTX-A or incoBTX-A injections, but the number of those was not reported, and neither were the outcomes according to spasticity aetiology; therefore, no remark could be made. To date, high doses of BTX-A have been predominantly used in treating post-stroke spasticity. The explanation of limited use only for stroke may be attributed to several reasons: 1) the long-term experience and familiarisation in injecting post-stroke subjects; 2) the complexity of neurological features with coexistent symptoms including apraxia, ataxia, fatigue and weakness other than spasticity such as in MS; 3) the availability of licensed BTX-A formulations and authorisation for injecting in local post-stroke spasticity; 4) multi-level spasticity involving upper and lower limb requiring treatment and doses that might exceed dosage currently approved for each treatment session; 5) more definite objectives in the context of rehabilitative processes to reach specific functional outcomes by neurotoxin injections.

In regard to the last points, post-stroke patients can display a wide variety of features and spastic muscle patterns; herein the opportunity to adapt the dosage of therapeutic BTX injections accordingly and the need for more tailored treatment options and flexibility in doses to inject for sessions [10]. Indeed, surveys conducted in Europe and North America showed that physicians stated that they would inject higher doses of BTX for the treatment of spasticity, if indicated [75]. Furthermore, according to their opinions, the outcome and satisfaction of post-stroke patients could be improved by $75.8 \%$ and $78.8 \%$, respectively, by higher BTX-A doses than labelled [9]. Although the reduction of spasticity is widely demonstrated with BTX-A treatment, its impact on the improvement of functional outcomes remains debated and controversial. As aforementioned, a reduction in spasticity has a key role to reach functional outcomes with the intent to improve mobility and dexterity, achieve physiological movement patterns, reduce pain, facilitate nursing measures and avoid complications. However, some reviews have suggested that that some oriented-focused movements unequivocally improve after reduced spasticity as a result of BTX-A treatment, in particular in the upper limbs [76,77]. This finding was also observed after high-dose BTX-A injections [35,36,38].

Weakness is one the main complication and concern in treating spasticity by BTX-A. In this respect, when reducing muscular tone, it has to be taken into account that muscle hyperactivity may have positive functional aspects, such as stabilising paretic limbs. Moreover, treating muscle hyperactivity does not always improve coexisting paresis. Indeed, treatment plans must consider a trade-off between a reduction in spastic hypertonia and the preservation of residual motor function [78]. In the present review, doses of BTX-A above 600 U produced transient weakness and local mild AEs in almost studies, but no serious AEs were observed. Kirshblum et al. reported an increase in AEs but suggested that the benefits of high dose BTX-A may outweigh the risks of AEs and may be clinically acceptable in certain patients [29]. The present review showed that among BTX-A formulations, onaBTX-A and incoBTX-A were used and of these, incoBTX-A was mainly injected though not authorised for LLS. IncoBTX-A is a purified neurotoxin without complexing proteins, and it may be argued that this formulation lacking accessory proteins has been considered to be less likely to lead to the development of Nab. Thus, patients are more able to adapt to high doses and this lends itself towards flexible dosage use in treating spasticity. However, high doses of both incoBTX-A and onaBTX-A resulted in efficacy and safety at doses between $600-840 \mathrm{U}[11,12,28,29,34-39,43]$ and dosages up to $1200 \mathrm{U}$ [39] were injected without occurrence of $\mathrm{Nab}$ or serious AEs. 
An important and widely debated issue concerns the cost-utility of BTX-A compared to the benefit gained, particularly in treating post-stroke spasticity. Investigations have demonstrated that aboBTX-A adjunct to rehabilitation produces a higher number of quality-adjusted life years compared to rehabilitation alone either in treating ULS [79] or post-stroke spasticity [80], and this therapeutic approach might be a cost-effective healthcare program for treating these patients [80]. In the present review, none of the studies included reported the cost-effectiveness of high BTX-A injection in treating spasticity, regardless of the aetiology.

To date, many questions remain unsolved regarding the use of high-dose BTX-A in treating adults with spasticity following CNS damage. Therefore, future well-designed studies should be planned to address the following issues:

- What subjects and spastic patients are suitable to undergo high-dose BTX-A treatment. This is particularly the case if the same benefit is not achievable with the recommended dosage under expert and proper guidance in muscle injection.

- If both UL and LL or multilevel segments of body sites should be injected for each injection cycle.

- The maximum doses for muscles and what is the maximum dosage to inject within the same session.

- The interval of injection, the length of the duration effect and long-term follow-up.

- The specific objectives and functional goals within rehabilitation processes to improve dexterity and quality of life.

- The cost-effectiveness of high dose BTX-A.

\section{Conclusions}

The global dosage injected per muscle or multiple muscle groups has progressively increased over time and both onaBTX-A and incoBTX-A high doses have been injected in treating spasticity following CNS damage, particularly in post-stroke patients. We identified few investigations with small numbers of subjects that investigated the treatment of spasticity following brain injury, and no studies were retrieved that ascertained the efficacy and safety of high-dose BTX-A in reducing spasticity following MS and SCI. The studies investigating high dose BTX-A in post-stroke spasticity had variable method designs and there was insufficient evidence to recommend routine high dose incoBTX-A and onaBTX-A use in clinical practice. However, dosages of these neurotoxins up $840 \mathrm{U}$ were efficacious and had a good safety profile without serious adverse events. In selected patients, the benefits of high-dose BTX-A may outweigh the risks of AEs and may be clinically acceptable. Several issues should be addressed by proper well-designed, planned studies; meanwhile, the functional benefit compared to risks should be taken into account when using high-dose BTX-A.

\section{Materials and Methods}

A search of relevant studies was conducted in MEDLINE/PubMed, the Cochrane Central Register of Controlled Trials, CINAHL, EMBASE, Web of Science and Scopus databases. We included English language reports from the international literature published from January 1989 to February 2020. Search terms varied slightly across databases but included "botulinum toxin", "botulinum toxin type A", "spasticity", "botulinum toxin high doses" "botulinum toxin high dosage", "post-stroke spasticity", "upper and lower limb spasticity", "brain injury", "multiple sclerosis", "spinal cord injury" and "adverse events". We search for "randomized controlled trial" as either MeSH terms, keywords or subject headings. Related terms were combined using the Boolean "OR" and "AND". Search limits included only adults. We did not include congress abstracts/posters or articles that were not peer-reviewed. Studies were included if: (1) they were homogenous or mixed samples studies enrolling subjects who suffered from spasticity following stroke, brain injury, multiple sclerosis and spinal cord injury; 2) the sample size included four or more subjects; 3) BTX-A formulations licensed by the USA and European authorities were used; 4) doses of BTX-A higher 600 U were injected, regardless 
of the aim of the study; 5) high doses of BTX-A were injected alone or combined with adjunctive interventions. Studies that investigated high BTX-A dosage in children with spasticity were excluded.

Author Contributions: All authors contributed to the study: D.I.; A.S., and F.D.R. conceived and planned the review; methodology: V.S., M.T.G. and M.R. conducted search literature and screened papers; D.I., A.S. and M.B. reviewed and discussed the studies; V.S., M.T.G. and F.D.R. collected data; D.I. and M.B. wrote the manuscript and prepared original draft. All authors have read and agreed to the published version of the manuscript.

Funding: This research was funded by research grant from the Italian Research Ministry

Conflicts of Interest: The authors declare no conflict of interest.

\section{References}

1. Lance, J.W. Symposium Synopsis. In Spasticity: Disordered Motor Control; Feldman, R.G., Young, R.R., Koella, W.P., Eds.; Yearbook Medical: Chicago, IL, USA, 1980; pp. 485-494.

2. Andringa, A.; van Wegen, E.; van de Port, I.; Kwakkel, G.; Meskers, C. Measurement Properties of the NeuroFlexor Device for Quantifying Neural and Non-neural Components of Wrist Hyper-Resistance in Chronic Stroke. Front. Neurol. 2019, 10, 730. [CrossRef] [PubMed]

3. Rekand, T.; Biering-Sörensen, B.; He, J.; Vilholm, O.J.; Christensen, P.B.; Ulfarsson, T.; Belusa, R.; Ström, T.; Myrenfors, P.; Maisonobe, P.; et al. Botulinum toxin treatment of spasticity targeted to muscle endplates: An international, randomised, evaluator-blinded study comparing two different botulinum toxin injection strategies for the treatment of upper limb spasticity. BMJ Open 2019, 9, e024340. [CrossRef] [PubMed]

4. Francisco, G.E. Botulinum toxin: Dosing and dilution. Am. J. Phys. Med. Rehabil. 2004, 83 (Suppl. 10), S30-S37. [CrossRef]

5. Wissel, J.; Ward, A.B.; Erztgaard, P.; Bensmail, D.; Hecht, M.J.; Lejeune, T.M.; Schnider, P.; Altavista, M.C.; Cavazza, S.; Deltombe, T.; et al. European consensus table on the use of botulinum toxin type A in adult spasticity. J. Rehabil. Med. 2009, 41, 13-25. [CrossRef]

6. Esquenazi, A.; Wein, T.H.; Ward, A.B.; Geis, C.; Liu, C.; Dimitrova, R. Optimal Muscle Selection for OnabotulinumtoxinA Injections in Poststroke Lower-Limb Spasticity: A Randomized Trial. Am. J. Phys. Med. Rehabil. 2019, 98, 360-368. [CrossRef]

7. López de Munain, L.; Valls-Solé, J.; Garcia Pascual, I.; Maisonobe, P. On Behalf of the VALGAS Investigators Group. Botulinum Toxin Type A Improves Function According to Goal Attainment in Adults with Poststroke Lower Limb Spasticity in Real Life Practice. Eur. Neurol. 2019, 82, 1-8.

8. Picelli, A.; Baricich, A.; Cisari, C.; Paolucci, S.; Smania, N.; Sandrini, G. The Italian real-life post-stroke spasticity survey: Unmet needs in the management of spasticity with botulinum toxin type A. Funct. Neurol. 2017, 32, 89-96. [CrossRef]

9. Bensmail, D.; Hanschmann, A.; Wissel, J. Satisfaction with botulinum toxin treatment in post-stroke spasticity: Results from two cross-sectional surveys (patients and physicians). J. Med. Econ. 2014, 17, 618-625. [CrossRef]

10. Wissel, J. Towards flexible and tailored botulinum neurotoxin dosing regimens for focal dystonia and spasticity-Insights from recent studies. Toxicon 2018, 147, 100-106. [CrossRef]

11. Dressler, D.; Saberi, F.A.; Kollewe, K.; Schrader, C. Safety aspects of incobotulinumtoxinA high-dose therapy. J. Neural. Transm. 2015, 122, 327-333. [CrossRef]

12. Chiu, S.Y.; Patel, B.; Burns, M.R.; Legacy, J.; Shukla, A.W.; Ramirez-Zamora, A.; Deeb, W.; Malaty, I.A. High-dose Botulinum Toxin Therapy: Safety, Benefit, and Endurance of Efficacy. Tremor Other Hyperkinetic Mov. 2020, 27, 10 .

13. Aoki, K.R.; Guyer, B. Botulinum toxin type A and other botulinum toxin serotypes: A comparative review of biochemical and pharmacological actions. Eur. J. Neurol. 2001, 8 (Suppl. 5), 21-29. [CrossRef] [PubMed]

14. Dressler, D.; Mander, G.; Fink, K. Measuring the potency labelling of onabotulinumtoxinA (Botox@) and incobotulinumtoxinA (Xeomin@) in an LD50 assay. J. Neural. Transm. 2012, 119, 13-15. [CrossRef] [PubMed]

15. Ranoux, D.; Gury, C.; Fondarai, J.; Mas, J.L.; Zuber, M. Respective potencies of Botox and Dysport: A double blind, randomised, crossover study in cervical dystonia. J. Neurol. Neurosurg. Psychiatry 2002, 72, 459-462. 
16. Sampaio, C.; Ferreira, J.J.; Simões, F.; Rosas, M.J.; Magalhães, M.; Correia, A.P.; Bastos-Lima, A.; Martins, R.; Castro-Caldas, A. DYSBOT: A single-blind, randomized parallel study to determine whether any differences can be detected in the efficacy and tolerability of two formulations of botulinum toxin type A-Dysport and Botox-Assuming a ratio of 4:1. Mov. Disord. 1997, 12, 1013-1018. [CrossRef] [PubMed]

17. Lundström, E.; Terént, A.; Borg, J. Prevalence of disabling spasticity 1 year after first-ever stroke. Eur. J. Neurol. 2008, 15, 533-539. [CrossRef]

18. Urban, P.P.; Wolf, T.; Uebele, M.; Marx, J.J.; Vogt, T.; Stoeter, P.; Bauermann, T.; Weibrich, C.; Vucurevic, G.D.; Schneider, A.; et al. Occurrence and clinical predictors of spasticity after ischemic stroke. Stroke 2010, 41, 2016-2020. [CrossRef]

19. Kong, K.H.; Lee, J.; Chua, K.S. Occurrence and temporal evolution of upper limb spasticity in stroke patients admitted to a rehabilitation unit. Arch. Phys. Med. Rehabil. 2012, 93, 143-148. [CrossRef]

20. Elia, A.E.; Filippini, G.; Calandrella, D.; Albanese, A. Botulinum neurotoxins for post-stroke spasticity in adults: A systematic review. Mov. Disord. 2009, 24, 801-812. [CrossRef]

21. Rosales, R.L.; Chua-Yap, A.S. Evidence-based systematic review on the efficacy and safety of botulinum toxin-A therapy in post-stroke spasticity. J. Neural. Transm. 2008, 115, 617-623. [CrossRef]

22. Wu, T.; Li, J.H.; Song, H.X.; Dong, Y. Effectiveness of Botulinum Toxin for Lower Limbs Spasticity after Stroke: A Systematic Review and Meta-Analysis. Top. Stroke Rehabil. 2016, 23, 217-223. [CrossRef] [PubMed]

23. Sun, L.C.; Chen, R.; Fu, C.; Chen, Y.; Wu, Q.; Chen, R.; Lin, X.; Luo, S. Efficacy and Safety of Botulinum Toxin Type A for Limb Spasticity after Stroke: A Meta-Analysis of Randomized Controlled Trials. BioMed Res. Int. 2019, 2019, 8329306. [CrossRef] [PubMed]

24. Santamato, A.; Micello, M.F.; Ranieri, M.; Valeno, G.; Albano, A.; Baricich, A.; Cisari, C.; Intiso, D.; Pilotto, A.; Logroscino, G.; et al. Employment of higher doses of botulinum toxin type A to reduce spasticity after stroke. J. Neurol. Sci. 2015, 350, 1-6. [CrossRef] [PubMed]

25. Santamato, A.; Ranieri, M.; Solfrizzi, V.; Lozupone, M.; Vecchio, M.; Daniele, A.; Greco, A.; Seripa, D.; Logroscino, G.; Panza, F. High doses of incobotulinumtoxinA for the treatment of post-stroke spasticity: Are they safe and effective. Expert Opin. Drug Metab. Toxicol. 2016, 12, 843-846. [CrossRef]

26. Baricich, A.; Picelli, A.; Santamato, A.; Carda, S.; de Sire, A.; Smania, N.; Cisari, C.; Invernizzi, M. Safety Profile of High-Dose Botulinum Toxin Type A in Post-Stroke Spasticity Treatment. Clin. Drug Investig. 2018, 38, 991-1000. [CrossRef]

27. Mancini, F.; Sandrini, G.; Moglia, A.; Nappi, G.; Pacchetti, C. A randomised, double-blind, dose-ranging study to evaluate efficacy and safety of three doses of botulinum toxin type A (Botox) for the treatment of spastic foot. Neurol. Sci. 2005, 26, 26-31. [CrossRef]

28. Baricich, A.; Grana, E.; Carda, S.; Santamato, A.; Molinari, C.; Cisari, C.; Invernizzi, M. Heart Rate Variability modifications induced by high doses of incobotulinumtoxinA and onabotulinumtoxinA in hemiplegic chronic stroke patients: A single blind randomized controlled, crossover pilot study. Toxicon 2017, 138, 145-150. [CrossRef]

29. Kirshblum, S.; Solinsky, R.; Jasey, N.; Hampton, S.; Didesch, M.; Seidel, B.; Botticello, A. Adverse Event Profiles of High Dose Botulinum Toxin Injections for Spasticity. PM R 2019. [CrossRef]

30. Hesse, S.; Jahnke, M.T.; Luecke, D.; Mauritz, K.H. Short-term electrical stimulation enhances the effectiveness of Botulinum toxin in the treatment of lower limb spasticity in hemiparetic patients. Neurosci. Lett. 1995, 201, 37-40. [CrossRef]

31. Varghese-Kroll, E.; Elovic, E.P. Contralateral weakness and fatigue after high-dose botulinum toxin injection for management of poststroke spasticity. Am. J. Phys. Med. Rehabil. 2009, 88, 495-499. [CrossRef]

32. Thomas, A.M.; Simpson, D.M. Contralateral weakness following botulinum toxin for poststroke spasticity. Muscle Nerve 2012, 46, 443-448. [CrossRef] [PubMed]

33. Crowner, B.E.; Torres-Russotto, D.; Carter, A.R.; Racette, B.A. Systemic weakness after therapeutic injections of botulinum toxin a: A case series and review of the literature. Clin. Neuropharmacol. 2010, 33, 243-247. [CrossRef] [PubMed]

34. Baricich, A.; Grana, E.; Carda, S.; Santamato, A.; Cisari, C.; Invernizzi, M. High doses of onabotulinumtoxinA in post-stroke spasticity: A retrospective analysis. J. Neural. Transm. 2015, 122, 1283-1287. [CrossRef] [PubMed] 
35. Santamato, A.; Panza, F.; Ranieri, M.; Frisardi, V.; Micello, M.F.; Filoni, S.; Fortunato, F.; Intiso, D.; Basciani, M.; Logroscino, G.; et al. Efficacy and safety of higher doses of botulinum toxin type A NT 201 free from complexing proteins in the upper and lower limb spasticity after stroke. J. Neural. Transm. 2013, 120, 469-476. [CrossRef]

36. Santamato, A.; Panza, F.; Intiso, D.; Baricich, A.; Picelli, A.; Smania, N.; Fortunato, F.; Seripa, D.; Fiore, P.; Ranieri, M. Long-term safety of repeated high doses of incobotulinumtoxinA injections for the treatment of upper and lower limb spasticity after stroke. J. Neurol. Sci. 2017, 378, 182-186. [CrossRef]

37. Invernizzi, M.; Carda, S.; Molinari, C.; Stagno, D.; Cisari, C.; Baricich, A. Heart Rate Variability (HRV) modifications in adult hemiplegic patients after botulinum toxin type A (nt-201) injection. Eur. J. Phys. Rehabil. Med. 2015, 51, 353-359. [CrossRef]

38. Wissel, J.; Bensmail, D.; Ferreira, J.J.; Molteni, F.; Satkunam, L.; Moraleda, S.; Rekand, T.; McGuire, J.; Scheschonka, A.; Flatau-Baqué, B.; et al. TOWER study investigators. Safety and efficacy of incobotulinumtoxinA doses up to $800 \mathrm{U}$ in limb spasticity: The TOWER study. Neurology 2017, 88, 1321-1328. [CrossRef]

39. Ianieri, G.; Marvulli, R.; Gallo, G.A.; Fiore, P.; Megna, M. “Appropriate Treatment" and Therapeutic Window in Spasticity Treatment with IncobotulinumtoxinA: From 100 to 1000 Units. Toxins 2018, 10, 140. [CrossRef]

40. Gracies, J.M.; Brashear, A.; Jech, R.; McAllister, P.; Banach, M.; Valkovic, P.; Walker, H.; Marciniak, C.; Deltombe, T.; Skoromets, A.; et al. International AbobotulinumtoxinA Adult Upper Limb Spasticity Study Group. Safety and efficacy of abobotulinumtoxinA for hemiparesis in adults with upper limb spasticity after stroke or traumatic brain injury: A double-blind randomised controlled trial. Lancet Neurol. 2015, 14, 992-1001. [CrossRef]

41. McAllister, P.J.; Khatkova, S.E.; Faux, S.G.; Picaut, P.; Raymond, R.; Gracies, J.M. Effects on walking of simultaneous upper/lower limb abobotulinumtoxina injections in patients with stroke or brain injury with spastic hemiparesis. J. Rehabil. Med. 2019, 51, 813-816. [CrossRef]

42. Dong, Y.; Wu, T.; Hu, X.; Wang, T. Efficacy and safety of botulinum toxin type A for upper limb spasticity after stroke or traumatic brain injury: A systematic review with meta-analysis and trial sequential analysis. Eur. J. Phys. Rehabil. Med. 2017, 53, 256-267. [PubMed]

43. Intiso, D.; Simone, V.; Di Rienzo, F.; Iarossi, A.; Pazienza, L.; Santamato, A.; Maruzzi, G.; Basciani, M. High doses of a new botulinum toxin type A (NT-201) in adult patients with severe spasticity following brain injury and cerebral palsy. NeuroRehabilitation 2014, 34, 515-522. [CrossRef] [PubMed]

44. Rizzo, M.A.; Hadjimichael, O.C.; Preiningerova, J.; Vollmer, T.L. Prevalence and treatment of spasticity reported by multiple sclerosis patients. Mult Scler. 2004, 10, 589-595. [CrossRef] [PubMed]

45. Pozzilli, C. Advances in management of multiple sclerosis spasticity: Experiences from recent studies and everyday clinical practice. Expert Rev. Neurother. 2013, 13 (Suppl. 12), 49-54. [CrossRef] [PubMed]

46. Ni, J.; Wang, X.; Cao, N.; Si, J.; Gu, B. Is repeat Botulinum Toxin A injection valuable for neurogenic detrusor overactivity-A systematic review and meta-analysis. Neurourol. Urodyn. 2018, 37, 542-553. [CrossRef] [PubMed]

47. Fu, X.; Wang, Y.; Wang, C.; Wu, H.; Li, J.; Li, M.; Ma, Q.; Yang, W. A mixed treatment comparison on efficacy and safety of treatments for spasticity caused by multiple sclerosis: A systematic review and network meta-analysis. Clin. Rehabil. 2018, 32, 713-721. [CrossRef]

48. Safarpour, Y.; Mousavi, T.; Jabbari, B. Botulinum Toxin Treatment in Multiple Sclerosis-a Review. Curr. Treat. Options Neurol. 2017, 19,33. [CrossRef]

49. Dressler, D.; Bhidayasiri, R.; Bohlega, S.; Chahidi, A.; Chung, T.M.; Ebke, M.; Jacinto, L.J.; Kaji, R.; Koçer, S.; Kanovsky, P.; et al. Botulinum toxin therapy for treatment of spasticity in multiple sclerosis: Review and recommendations of the IAB-Interdisciplinary Working Group for Movement Disorders task force. J. Neurol. 2017, 264, 112-120. [CrossRef]

50. Snow, B.J.; Tsui, J.K.; Bhatt, M.H.; Varelas, M.; Hashimoto, S.A.; Calne, D.B. Treatment of spasticity with botulinum toxin: A double-blind study. Ann. Neurol. 1990, 28, 512-515. [CrossRef]

51. Grazko, M.A.; Polo, K.B.; Jabbari, B. Botulinum toxin A for spasticity, muscle spasms, and rigidity. Neurology 1995, 45, 712-717. [CrossRef] 
52. Hyman, N.; Barnes, M.; Bhakta, B.; Cozens, A.; Bakheit, M.; Kreczy-Kleedorfer, B.; Poewe, W.; Wissel, J.; Bain, P.; Glickman, S.; et al. Botulinum toxin (Dysport) treatment of hip adductor spasticity in multiple sclerosis: A prospective, randomised, double blind, placebo controlled, dose ranging study. J. Neurol. Neurosurg. Psychiatry 2000, 68, 707-712. [CrossRef] [PubMed]

53. Comi, G.; Solari, A.; Leocani, L.; Centonze, D.; Otero-Romero, S. Italian Consensus Group on treatment of spasticity in multiple sclerosis. Italian consensus on treatment of spasticity in multiple sclerosis. Eur. J. Neurol. 2020, 27, 445-453. [CrossRef] [PubMed]

54. Giovannelli, M.; Borriello, G.; Castri, P.; Prosperini, L.; Pozzilli, C. Early physiotherapy after injection of botulinum toxin increases the beneficial effects on spasticity in patients with multiple sclerosis. Clin. Rehabil. 2007, 21, 331-337. [CrossRef] [PubMed]

55. Paoloni, M.; Giovannelli, M.; Mangone, M.; Leonardi, L.; Tavernese, E.; Di Pangrazio, E.; Bernetti, A.; Santilli, V.; Pozzilli, C. Does giving segmental muscle vibration alter the response to botulinum toxin injections in the treatment of spasticity in people with multiple sclerosis? A single-blind randomized controlled trial. Clin. Rehabil. 2013, 27, 803-812. [CrossRef]

56. Konstanzer, A.; Ceballos-Baumann, A.O.; Dressnandt, J.; Conrad, B. Local injection treatment with botulinum toxin A in severe arm and leg spasticity. Nervenarzt 1993, 64, 517-523.

57. Sobolewski, P. The application of botulinum toxin type A in the treatment of spastic paraparesis. Przegl. Lek. 2007, 64 (Suppl. 2), 3-7.

58. Gold, R.; Oreja-Guevara, C. Advances in the management of multiple sclerosis spasticity: Multiple sclerosis spasticity guidelines. Expert Rev. Neurother. 2013, 13 (Suppl. 12), 55-59. [CrossRef]

59. Tibbett, J.A.; Field-Fote, E.C.; Thomas, C.K.; Widerström-Noga, E.G. Spasticity and Pain after Spinal Cord Injury: Impact on Daily Life and the Influence of Psychological Factors. PM R 2020, 12, 119-129. [CrossRef]

60. Hebert, K.P.; Klarskov, N.; Bagi, P.; Biering-Sørensen, F.; Elmelund, M. Long term continuation with repeated Botulinum toxin A injections in people with neurogenic detrusor overactivity after spinal cord injury. Spinal Cord 2020. [CrossRef]

61. Mehta, S.; Hill, D.; McIntyre, A.; Foley, N.; Hsieh, J.; Ethans, K.; Teasell, R.W.; Loh, E.; Welk, B.; Wolfe, D. Meta-analysis of botulinum toxin A detrusor injections in the treatment of neurogenic detrusor overactivity after spinal cord injury. Arch. Phys. Med. Rehabil. 2013, 94, 1473-1481. [CrossRef]

62. De Icco, R.; Perrotta, A.; Berra, E.; Allena, M.; Alfonsi, E.; Tamburin, S.; Serrao, M.; Sandrini, G.; Tassorelli, C. OnabotulinumtoxinA Reduces Temporal Pain Processing at Spinal Level in Patients with Lower Limb Spasticity. Toxins 2019, 11, 359. [CrossRef] [PubMed]

63. Chun, A.; Levy, I.; Yang, A.; Delgado, A.; Tsai, C.Y.; Leung, E.; Taylor, K.; Kolakowsky-Hayner, S.; Huang, V.; Escalon, M.; et al. Treatment of at-level spinal cord injury pain with botulinum toxin A. Spinal Cord Ser. Cases 2019, 5, 77. [CrossRef] [PubMed]

64. Intiso, D.; Basciani, M.; Santamato, A.; Intiso, M.; Di Rienzo, F. Botulinum Toxin Type A for the Treatment of Neuropathic Pain in Neuro-Rehabilitation. Toxins 2015, 7, 2454-2480. [CrossRef] [PubMed]

65. Adams, M.M.; Hicks, A.L. Spasticity after spinal cord injury. Spinal Cord 2005, 43, 577-586. [CrossRef]

66. Holtz, K.A.; Lipson, R.; Noonan, V.K.; Kwon, B.K.; Mills, P.B. Prevalence and Effect of Problematic Spasticity After Traumatic Spinal Cord Injury. Arch. Phys. Med. Rehabil. 2017, 98, 1132-1138. [CrossRef]

67. Palazón-García, R.; Alcobendas-Maestro, M.; Esclarin-de Ruz, A.; Benavente-Valdepeñas, A.M. Treatment of spasticity in spinal cord injury with botulinum toxin. J. Spinal Cord Med. 2019, 42, 281-287. [CrossRef]

68. Yan, X.; Lan, J.; Liu, Y.; Miao, J. Efficacy and Safety of Botulinum Toxin Type A in Spasticity Caused by Spinal Cord Injury: A Randomized, Controlled Trial. Med. Sci. Monit. 2018, 24, 8160-8171. [CrossRef]

69. Dressler, D. Routine use of Xeomin ${ }^{\circledR}$ in patients previously treated with Botox ${ }^{\circledR}$ : Long term results. Eur. J. Neurol. 2009, 16 (Suppl. 2), 2-5. [CrossRef]

70. Bakheit, A.M.; Ward, C.D.; McLellan, D.L. Generalised botulism-like syndrome after intramuscular injections of botulinum toxin type A: A report of two cases. J. Neurol. Neurosurg. Psychiatry 1997, 62, 198. [CrossRef]

71. Turkel, C.C.; Bowen, B.; Liu, J.; Brin, M.F. Pooled analysis of the safety of botulinum toxin type A in the treatment of poststroke spasticity. Arch. Phys. Med. Rehabil. 2006, 87, 786-792. [CrossRef]

72. Jankovic, J.; Schwartz, K. Response and immunoresistance to botulinum toxin injections. Neurology 1995, 45, 1743-1746. [CrossRef] [PubMed] 
73. Naumann, M.; Carruthers, A.; Carruthers, J.; Aurora, S.K.; Zafonte, R.; Abu-Shakra, S.; Boodhoo, T.; Miller-Messana, M.A.; Demos, G.; James, L.; et al. Meta-analysis of neutralizing antibody conversion with onabotulinumtoxinA (BOTOX1) across multiple indications. Mov. Disord. 2010, 25, 2211-2218. [CrossRef] [PubMed]

74. Mathevon, L.; Declemy, A.; Laffont, I.; Perennou, D. Immunogenicity induced by botulinum toxin injections for limb spasticity: A systematic review. Ann. Phys. Rehabil. Med. 2019, 62, 241-251. [CrossRef] [PubMed]

75. Wissel, J.; Harriss, J.P.; Simon, O.; Sternberg, K.; Roche, N.; Cantú-Brito, C.; Khatkova, S.E.; Säterö, P. Poster 370 An International, Observational Study of Botulinum Toxin Type A in Spasticity-SPAsticity in PractiCE (SPACE). PM R J. Inj. Funct. Rehabil. 2016, 8, S281. [CrossRef] [PubMed]

76. Intiso, D.; Simone, V.; Di Rienzo, F.; Santamato, A.; Russo, M.; Tolfa, M.; Basciani, M. Does Spasticity Reduction by Botulinum Toxin Type A Improve Upper Limb Functionality in Adult Post-Stroke Patients? A Systematic Review of Relevant Studies. J. Neurol. Neurophysiol. 2013, 4, 1-12.

77. Foley, N.; Pereira, S.; Salter, K.; Fernandez, M.M.; Speechley, M.; Sequeira, K.; Miller, T.; Teasell, R. Treatment with botulinum toxin improves upper-extremity function post stroke: A systematic review and meta-analysis. Arch. Phys. Med. Rehabil. 2013, 94, 977-989. [CrossRef]

78. Woldag, H.; Hummelsheim, H. Is the reduction of spasticity by botulinum toxin a beneficial for the recovery of motor function of arm and hand in stroke patients? Eur. Neurol. 2003, 50, 165-171. [CrossRef]

79. Shackley, P.; Shaw, L.; Price, C.; van Wijck, F.; Barnes, M.; Graham, L.; Ford, G.A.; Steen, N.; Rodgers, H. Cost-effectiveness of treating upper limb spasticity due to stroke with botulinum toxin type A: Results from the botulinum toxin for the upper limb after stroke (BoTULS) trial. Toxins 2012, 4, 1415-1426. [CrossRef]

80. Lazzaro, C.; Baricich, A.; Picelli, A.; Caglioni, P.M.; Ratti, M.; Santamato, A. AbobotulinumtoxinA and rehabilitation vs. rehabilitation alone in post-stroke spasticity: A cost-utility analysis. J. Rehabil. Med. 2020, 52, jrm00016. [CrossRef]

(C) 2020 by the authors. Licensee MDPI, Basel, Switzerland. This article is an open access article distributed under the terms and conditions of the Creative Commons Attribution (CC BY) license (http://creativecommons.org/licenses/by/4.0/). 